\title{
Monba Chinese
}

National Cancer Institute

\section{Source}

National Cancer Institute. Monba Chinese. NCI Thesaurus. Code C158207.

A Chinese person from the Monba ethnic group. 